\title{
PENGETAHUAN PASIEN TENTANG PENYAKIT DEMAM BERDARAH DENGUE DI POLIKLINIK UMUM PUSKESMAS POASIA KOTA KENDARI
}

\author{
Taamu, Sitti Rachmi Misbah, Arif Purnama \\ Jurusan Keperawatan Poltekkes Kemenkes Kendari
}

\begin{abstract}
Dengue hemorrhagic fever is a disease caused by dengue virus that enter into human body through Aedes aegypti mosquito bites. Dengue Hemorrhagic Fever case in Southeast Sulawesi province from January to February 2016 has reached 530 cases with 3 deaths or 0,57\%. This study aims to determine the description of patient knowledge about the causes, signs and symptoms, prevention and management of dengue fever. The sample in this research is obtained by accidental sampling technique as many as 82 people from the total population of 821 people who are patients in Public Health Center of Kendari Polyclinic. The results showed that the patient had sufficient knowledge of DHF on the aspect of cause as much as $(43,9 \%)$, sign and symptom aspect as much $(53,66 \%)$, prevention aspect as much $(50,00 \%)$ while the management aspect, $(45.12 \%)$. The conclusion of this study is that the majority of patients in the Public Polyclinic of Poasia City Health Center have sufficient knowledge on the causal aspects, signs and symptoms and preventive measures against dengue hemorrhagic fever. While in the management aspect of dengue hemorrhagic disease majority of patients have knowledge of good.
\end{abstract}

\section{Keywords: Patient Knowledge, Dengue Fever}

\section{PENDAHULUAN}

Penyakit Demam Berdarah Dengue adalah penyakit menular yang disebabkan oleh virus Dengue dan nyamuk Aedes aegypti sebagai vector utamanya (Hasyim, 2013). Demam Berdarah Dengue ditandai dengan manifestasi klinis utama yaitu demam tinggi, fenomena hemoragik, sering dengan hepatomegali dan pada kasus berat ada tandatanda kegagalan sirkulasi. Penyakit ini ditemukan nyaris di seluruh belahan dunia terutama di negara-negara tropik dan subtropik baik sebagai penyakit endemik maupun epidemic (Rohmani 2013). Berdasarkan data World Health Organization (WHO), sekitar 2,5 miliyar orang atau dua perlima dari populasi dunia kini menghadapi resiko dari dengue dan memperkirakan bahwa mungkin 50 juta kasus infeksi dengue di seluruh dunia setiap tahunya (WHO 2007-2008).

Berdasarkan data IR DBD per Propinsi pada tahun 2013, teridentifikasi angka kesakitan DBD 112.511 kasus dengan angka kematian sebesar $0.77 \%$ atau 8711 kematian sedangkan pada tahun 2014 hingga pertengahan bulan Desember tercatat penderita DBD di 34 provinsi di Indonesia sebanyak 71.668 orang dan 641 atau $0,89 \%$ orang di antaranya meninggal dunia (Balitbangkes Kemenkes RI, 2014). Sementara kasus Demam Berdarah Dengue di wilayah Provinsi Sulawesi Tenggara

sepanjang Januari hingga Februari 2016 telah mencapai 530 kasus dengan 3 orang meninggal dunia atau sebesar 0,57\% (Dinkes Sultra, 2016).

Tingginya kasus DBD yang terjadi, perlu disikapi secara arif untuk melakukan upaya solutif dalam memberikan penanganan secara komprehensif. Secara umum, upaya penanganan terhadap DBD telah banyak dilakukan oleh pemerintah namun belum menunjukkan hasil yang memuaskan, sebagaimana diungkap oleh Kementerian Kesehatan RI bahwa Angka Kesakitan/ Incidence Rate (IR) DBD cenderung meningkat dari tahun ke tahun. Untuk meningkatkan derajat kesehatan dan mencegah berkembangnya penyakit demam berdarah dengue diperlukan pengetahuan yang baik terhadap penyakit DBD.

Hal ini juga didukung oleh pernyataan Asiah dkk (2014) yang menyatakan bahwa salah satu bentuk objek kesehatan dapat dijabarkan oleh pengetahuan yang diperoleh dari pengalaman sendiri, khususnya tentang penyebab, tanda dan gejala, pencegahan dan penatalaksanaan penyakit demam berdarah dengue. Rendahnya pengetahuan tentang penyakit Demam Berdarah Dengue sejalan dengan munculnya resiko terkena Demam Berdarah Dengue. Pengetahuan kepada masyarakat diperlukan karena sebagai modal awal perubahan perilaku masyarakat. 
Pengetahuan tentang penyakit Demam Berdarah Dengue (DBD) menjadi hal yang sangat penting diketahui oleh masyarakat sehingga dapat melakukan deteksi dini dan mampu mengetahui tentang penyebab, tanda dan gejala, pencegahan dan cara penatalaksanaan Demam Berdarah Dengue (DBD).

Penelitian ini bertujuan (1) Untuk mengetahui pengetahuan pasien tentang Penyakit Demam Berdarah Dengue (DBD) berdasarkan penyebab di Poliklinik Umum Puskesmas Poasia Kota Kendari Tahun 2016. (2) Untuk mengetahui pengetahuan pasien tentang Penyakit Demam Berdarah Dengue (DBD) berdasarkan tanda dan gejala di Poliklinik Umum Puskesmas Poasia Kota Kendari Tahun 2016. (3) Untuk mengetahui pengetahuan pasien tentang Penyakit Demam Berdarah Dengue (DBD) berdasarkan pencegahan di Poliklinik Umum Puskesmas Poasia Kota Kendari Tahun 2016. (4) Untuk mengetahui pengetahuan pasien tentang Penyakit Demam Berdarah Dengue (DBD) berdasarkan penatalaksanaan di Poliklinik Umum Puskesmas Poasia Kota Kendari Tahun 2016.

\section{METODE PENELITIAN \\ Jenis Penelitian}

Jenis penelitian ini adalah penelitian deskriptif yang dilakukan untuk mengetahui gambaran pengetahuan pasien tentang penyakit Demam Berdarah Dengue (DBD) di Poliklinik Umum Puskemas Kota Kendari.

\section{Waktu dan Tempat Penelitian}

Penelitian ini dilaksanakan pada tanggal $6-13$ Juni tahun 2016 di Poliklinik Umum Puskesmas Poasia Kota Kendari

\section{Populasi dan Sampel}

Populasi dalam penelitian ini adalah semua pasien di Poliklinik Umum Puskesmas Poasia Kota Kendari pada tahun 2016 pada bulan Januari dengan jumlah 821 orang dengan kasus kunjungan lama sebanyak 461 dan kunjungan baru sebanyak 360 orang.

Sampel ditentukan dengan tehnik accidental sampling yaitu pengambilan sampel yang kebetulan ada atau tersedia di Poliklinik Umum Puskesmas Poasia Kota Kendari sesuai dengan konteks penelitian yakni pasien yang datang berobat di Puskesmas.
Penentuan sampel dalam penelitian ini dilakukan dengan mempertimbangkan ruang lingkup penelitian dan karakterisitik tingkat pengetahuan pupulasi, serta merujuk pendapat Arikunto (2006: 112) bahwa pada jumlah subjek yang besar (>100) dapat diambil sampel $10 \%-15 \%$ sehingga dalam penelitian ini sampel yang digunakan sebesar 82 orang. Hal ini telah memenuhi kriteria yang disyaratkan oleh Roscoe dalam Sugiyono (2011: 90) bahwa ukurang sampel yang layak dalam suatu penelitian antara 30 sampai 500.

\section{Instrumen Penelitian}

Instrumen yang digunakan dalam penelitian ini adalah angket tertutup yaitu daftar pertanyaan tentang penyakit Demam Berdarah Dengue yang sudah tersusun dengan baik masingmasing 5 pertanyaan dengan pilihan jawaban "ya" atau "tidak".

\section{Teknik Pengumpulan Data}

Cara pengumpulan data dalam penelitian ini dilakukan dengan membagikan instrumen yang telah divalidasi dan reliabel kepada responden yang di pilih sebagai sampel tentang pengetahuan pasien tentang penyakit demam berdarah dengue.

Data yang digunakan dalam penelitian ini ada 2, yaitu:

1. Data primer

Data primer yang dimaksud dalam penelitian ini adalah pasien yang diambil dengan mengajukan permohonan untuk menjadi responden, bila responden bersedia dilanjutkan dengan menandatangani surat persetujuan menjadi responden dan selanjutnya dilanjutkan dengan pengambilan data dengan menggunakan kuesioner.

2. Data sekunder

Data sekunder yaitu data yang di peroleh dari catatan yang ada di Puskesmas Poasia Kota Kendari sesuai dengan keperluan pasien yaitu data tentang pasien dan gambaran tentang lokasi penelitian.

\section{Analisis Data}

Sesuai jenis penelitian ini yaitu kuantitatif dengan pendekatan survey deskriptif, maka analisis data dilakukan untuk mengetahui presentase setiap variabel yang diteliti.

\section{HASIL PENELITIAN}

Hasil penelitian ini disajikan secara deskriptif untuk menggambarkan tingkat pengetahuan 
pasien sesuai dengan tujuan penelitian. Aspek yang digambarkan berupa gambaran pengetahuan pasien tentang penyebab, tanda dan gejala, pencegahan serta penatalaksanaan penyakit Demam Berdarah Dengue (DBD).

Tabel 1. Distribusi Pengetahuan Pasien tentang Penyebab, Tanda dan Gejala, Pencegahan, dan Penatalaksanaan Penyakit Demam Berdarah Dengue di Poliklinik Umum Puskesmas Poasia Kota Kendari

\begin{tabular}{lcc}
\hline \multicolumn{1}{c}{ Tingkat Pengetahuan Pasien } & Frekuensi (Jiwa) & Persentase (\%) \\
\hline Pengetahuan tentang Penyebab Penyakit & 28 & 34,15 \\
Baik & 36 & 43,90 \\
Cukup & 18 & 21,95 \\
Kurang & $\mathbf{8 2}$ & $\mathbf{1 0 0 , 0}$ \\
Jumlah & & \\
Pengetahuan tentang Tanda dan Gejala & 22 & 26,83 \\
Penyakit & 44 & 53,66 \\
Baik & 16 & 19,51 \\
Cukup & $\mathbf{8 2}$ & $\mathbf{1 0 0 , 0}$ \\
Kurang & & \\
Jumlah & 31 & 37,80 \\
Pengetahuan tentang Pencegahan Penyakit & 41 & 50,00 \\
Baik & 10 & 12,20 \\
Cukup & $\mathbf{8 2}$ & $\mathbf{1 0 0 , 0}$ \\
Kurang & & \\
Jumlah & & 45,12 \\
Pengetahuan tentang Penatalaksanaan & 37 & 36,59 \\
Penyakit & 30 & 18,29 \\
Baik & 15 & $\mathbf{1 0 0 , 0}$ \\
Cukup & $\mathbf{8 2}$ & \\
Kurang & & \\
Jumlah &
\end{tabular}

Berdasarkan Tabel 1. diketahui bahwa mayoritas pasien memiliki pengetahuan yang cukup tentang penyebab terjadinya penyakit demam berdarah dengue yakni sebanyak 36 orang $(43,90 \%)$, sebanyak 28 orang $(31,15 \%)$ memiliki pengetahuan yang baik, dan hanya 18 orang $(21,95 \%)$ memiliki pengetahuan yang kurang.

Mayoritas pasien memiliki pengetahuan yang cukup tentang tanda dan gejala penyakit demam berdarah dengue yakni sebanyak 44 orang $(53,66 \%)$, sebanyak 22 orang $(26,83 \%)$ memiliki pengetahuan yang baik, dan hanya 16 orang $(19,51 \%)$ memiliki pengetahuan yang kurang.

Mayoritas pasien memiliki pengetahuan yang cukup tentang pencegahan penyakit demam berdarah dengue yakni sebanyak 41 orang $(50,00 \%$,$) , sebanyak 31$ orang $(37,80 \%)$ memiliki pengetahuan yang baik, dan hanya 10 orang $(12,20 \%)$ memiliki pengetahuan yang kurang.
Mayoritas pasien memiliki pengetahuan yang Baik tentang penatalaksanaan penyakit demam berdarah dengue yakni sebanyak 37 orang $(45,12 \%$,), sebanyak 30 orang $(36,59 \%)$ memiliki pengetahuan yang cukup, dan hanya 15 orang $(18,29 \%)$ memiliki pengetahuan yang kurang.

Secara rinci pengetahuan pasien di Puskesmas Poasia Kendari terhadap penyakit demam berdarah dengue disajikan pada histogram 1.

\section{PEMBAHASAN}

Pengetahuan adalah segala sesuatu yang diketahui oleh manusia sebagai hasil interaksi terhadap lingkungan maupun terhadap dirinya sendiri melalui proses kontemplasi. Sigarlaki (2007) menyatakan bahwa Pengetahuan merupakan hasil dari tahu dan ini terjadi setelah orang melakukan penginderaan terhadap suatu objek tertentu. Pengetahuan seseorang sangat dinamis terhadap gejala 
lingkungan yang menyertainya. pengetahuan setiap orang sangat variatif karena dipengaruhi oleh beberapa faktor.

Secara teoritis, pengetahuan sesorang dapat dipengaruhi oleh berbagai faktor baik faktor internal maupun faktor eksternal. Faktor internal berkaitan dengan kualitas diri seseorang yang dicerminkan melalui perilaku hidupnya. Sebagaimana diungkapkan oleh Satyawan dan Pasek (2013) bahwa pengetahuan merupakan domain yang sangat berperan untuk terbentuknya suatu tindakan seseorang, artinya perilaku seseorang merupakan cermin dari pengetahuannya. Selain itu, faktor eksternal yang berkaitan dengan pendidikan merupakan salah satu faktor dominan yang dapat mempengaruhi pola pikir seseorang untuk membangun pengetahuannya. Seseorang yang berpendidikan tinggi sangat memahami pentingnya informasi-informasi mutakhir tentang pola hidup sehat yang dapat membantu mereka terhindar dari berbagai jenis penyakit.

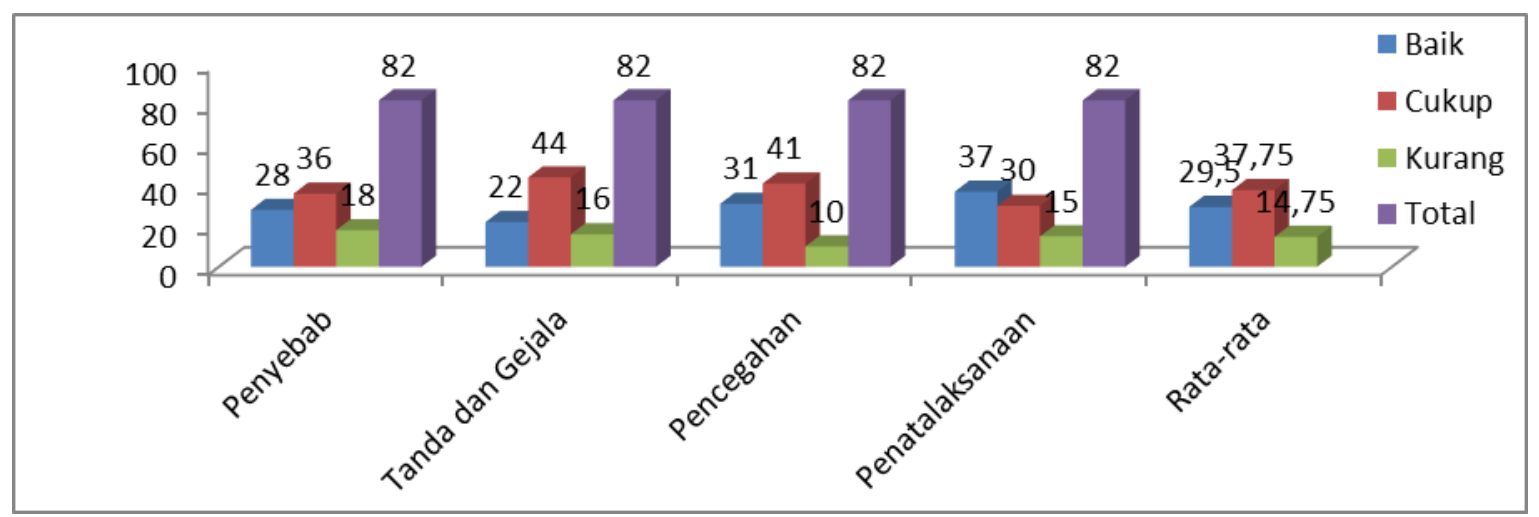

\section{Histogram 1. Pengetahuan Pasien terhadap Penyakit Demam Berdarah Dengue (DBD) di Poliklinik Umum Puskesmas Poasia Kota Kendari}

Distribusi tingkat pendidikan pasien di Puskesmas Poasia Kendari di dominasi oleh pasien yang berpendidikan setingkat SMA yakni sebanyak $(56,1 \%)$ dan setingkat $\mathrm{SD}$ sebanyak SD (7,3\%), hal ini memberikan gambaran bahwa pengetahuan pada tingkat pendidikan SMA belum cukup membekali masyarakat untuk menghindari penyakit DBD. meskipun ada juga pasien yang berpendidikan setingkat perguruan tinggi yakni sebanyak $(17,1 \%)$, namun jumlah itu tidak signifikan.

Hasil penelitian menunjukkan bahwa mayoritas pasien di puskesmas Poasia Kendari memiliki pengetahuan yang cukup terhadap penyakit DBD pada aspek penyebab sebanyak $(43,9 \%)$, aspek tanda dan gejala sebanyak $(53,66 \%)$, aspek pencegahan sebanyak $(50,00 \%)$ sedangkan aspek penatalaksanaan, mayoritas pasien memiliki pengetahuan yang baik sebanyak (45,12\%). Hasil tersebut menggambarkan adanya keterkaitan antara tingkat pendidikan pasien yang mayoritas setingkat SMA dengan pengetahuan pasien terhadap DBD pada kategori cukup. Meskipun pada penelitian ini belum dapat dijelaskan secara komprehensif atau secara statistic, namun secara parsial, hal tersebut di dukung oleh hasil penelitian Lumonga dan Ramasamy (2013) menyimpulkan bahwa semakin tinggi tingkat pendidikan seseorang semakin baik pula pengetahuannya. Dengan kata lain, semakin tinggi pendidikan seseorang makin mudah orang tersebut untuk menerima informasi, dan semakin banyak informasi yang masuk semakin banyak pula pengetahuan yang didapat.

Histogram 1. di atas menggambarkan bahwa pengetahuan pasien tentang penatalaksanaan DBD lebih baik dibandingkan dengan pengetahuan pasien pada aspek yang lain, itu tergambar dari distribusi pasien yang memiliki pengetahuan baik yakni $37(45,12 \%)$ orang merupakan yang tertinggi dibanding dengan aspek yang lainnya. Tetapi hal tersebut tidak cukup untuk menghindarkan mereka dari penyakit DBD. Herlambang (2011) menyatakan bahwa mencegah selalu lebih baik daripada mengobati, namun untuk dapat melakukan pencegahan terhadap penyakit seseorang perlu mengetahui penyebab dari penyakit tersebut.

Apabila kita amati secara seksama, distribusi pengetahuan pasien pada Histogram di atas, tampak bahwa pengetahuan pasien terhadap pencegahan penyakit DBD juga relative lebih baik dibandingkan dengan pengetahuan tentang penyebab maupun tentang tanda dan gejala penyakit DBD. Dimana sebanyak 31 orang $(37,80 \%)$ memiliki pengetahuan yang baik terhadap tindakan 
pencegahan penyakit $\mathrm{DBD}$, tetapi hal tersebut belum membuat mereka terhindar dari penyakit DBD. Sebagai ilustrasi bahwa salah satu tindakan pencegahan DBD yang dapat dilakukan adalah menghindari gigitan nyamuk Aedes aegypti yang merupakan penyebab penyakit DBD. Selanjutnya, seseorang dapat melakukan penatalaksananan penyakit DBD jika orang tersebut benar-benar yakin bahwa dia telah terjangkit penyakit DBD melalui tanda dan gejala yang tampak pada dirinya. Rangkaian ini menegaskan bahwa keempat aspek pengetahuan tersebut menjadi penting untuk dipahami secara holistik agar terhindar dari penyakit DBD.

Dengan demikian, berdasarkan data pengetahuan pasien, maka salah satu penyebab tingginya pasien DBD di puskesmas Poasia adalah kurangnya pengetahuan pasien terhadap penyakit DBD. Kurangnya pengetahuan mengakibatkan mereka cenderung pasif dalam melakukan tindakan pencegahan DBD. Sementara Budi (2015) dan Kaunang dkk (2016) menyimpulkan bahwa terdapat hubungan positif antara pengetahuan dengan tindakan pencegahan DBD. Sejalan dengan itu, Wahyuni dkk (2005) dalam penelitiannya mempertegas bahwa semakin kurang sikap seseorang atau masyarakat terhadap penanggulangan dan pencegahan penyakit DBD maka akan semakin besar kemungkinan timbulnya penyakit DBD.

Dalam hal ini, pengetahuan menjadi faktor kunci bagi masyarakat untuk menghindari penyakit DBD karena pengetahuan yang baik akan berimplikasi pada timbulnya perilaku hidup sehat yang baik. Sebagaimana diungkapkan oleh Nurhida dkk (2016) bahwa Pengetahuan seseorang berhubungan dengan perilakunya, demikian pula Kaunang dkk (2016) menyatakan bahwa Pengetahuan adalah salah satu faktor yang mempengaruhi perilaku manusia.

Pengetahuan berkaitan dengan pengalaman seseorang untuk menerima informasi, semakin banyak informasi yang masuk semakin banyak pula pengetahuan yang didapat. ditinjau dari aspek penatalaksanaan DBD, pasien di Puskesmas Poasia Kendari memiliki pengetahuan yang baik, dalam hal ini upaya untuk melakukan perawatan dapat diaplikasikan. Baiknya pengetahuan pasien terhadap tindakan penatalaksanaan mengindikasikan bahwa kesadaran akan kesehatan masih bersifat tradisional. kesadaran seperti ini perlu segera dimodernisasi dengan memberikan pemahaman tentang pentingnya mengetahui penyebab dan pencegahan penyakit, khusunya masyarakat pada tingkat pendidikan SMA ke bawah. Mereka perlu diberikan penyuluhan secara komprehensif tentang DBD, terutama aspek yang berkaitan langsung dengan tindakan konkrit yang mungkin dilakukan oleh masyarakat melalui penyuluhan dan seminar tentang penyakit DBD secara komprehensif dan berkesinambungan.

Selain penyebab dan pencegahan penyakit DBD, Pengetahuan tentang tanda gejala juga penting untuk dipahami sebab pengetahuan pasien tentang tanda dan gejala Demam Berdarah Dengue merupakan langkah awal untuk mengenal sejak dini munculnya penyakit demam berdarah. Jika tanda sudah ada, maka harus dilakukan prosedur penatalaksanaan yang baik agar tidak berakibat buruk bagi pasien. Jika pasien mengenali tanda dan gejala penyakit DBD maka salah satu langkah yang perlu dilakukan untuk penetalaksanaan awal adalah memberikan minum banyak, kompres hangat, minum obat penurun panas. Dalam penanganan hal ini apabila tidak terjadi perubahan, maka upaya yang harus dilakukan adalah segera membawa ke fasilitas pelayanan kesehatan untuk dilakukan tindak lanjut. Hal hanya dapat dilakukan bila pasien memiliki pengetahuan tentang penatalaksanaan tersebut.

\section{KESIMPULAN}

Berdasarkan hasil penelitian dan pembahasan dapat disimpulkan bahwa mayoritas pasien di Poliklinik Umum Puskesmas Poasia Kota Kendari memiliki pengetahuan yang cukup pada Aspek penyebab, tanda dan gejala serta tindakan pencegahan terhadap penyakit demam berdarah dengue. Sedangkan pada aspek penatalaksanaan penyakit Demam Berdarah Dengue mayoritas pasien memiliki pengetahuan yang baik.

\section{DAFTAR PUSTAKA}

Arikunto S. (2006). Prosedur Penelitian Suatu Pendekatan Praktik, Ed Revisi VI, Penerbit PT Rineka Cipta, Jakarta.

Asia, dkk. (2014). Gambaran Tingkat Pengetahuan Keluarga tentang Demam Berdarah Dengue Pada Anak Di Wilayah Kerja Puskesmas Blang Bintang Aceh Besar Tahun 2104. Serambi Saintia. 2(2): 125-134. 
Budi, H. (2015). Hubungan Tingkat Pengetahuan Warga tentang Demam Berdarah Dengan Upaya Pencegahan Demam Berdarah di Dukuh Gunung RT 01 RW 12 Desa Puncangan Kecamatan Kartasurya Kabupaten Sukoharjo. "Kosala" JIK. 3(2): 63.

Depkes RI. (2010). Profil Kesehatan Indonesia. Http://www.Depkes.go.id/downloads/ Profil_Kesehatan indonesia 2010.pdf. Diakses tanggal 19 Februari 2016.

Dinas Kesehatan Provinsi Sulawesi Tenggara. (2016). Dinas Kesehatan Provinsi Sulawesi Tenggara Tahun 2016. Kendari.

Hasyim, D. M. (2013). Faktor-faktor Yang Berhubungan dengan Tindakan Pemebrantasan Sarang Nyamuk Demam Berdarah Dengue (PSN DBD). IV (2): 365.

Kaunang, dkk. (2016). Hubungan Antara Pengetahuan Dan Sikap Dengan Tindakan Pencegahan Demam Berdarah Dengue (DBD) Di Kelurahan Malalayang 2 Lingkungan III. Pharmacon Jurnal Ilmiah Farmasi. 5(1): $382-389$.

Lumonga dan Ramasamy. (2013). Hubungan Tingkat Pendidikan dengan Tingkat Pengetahuan tentang Antenatal Care dalam Kalangan Ibu Usia Subur. EJournal FK USU. 1(1): $1-5$.

Notoatmodjo, S. (2010). Metodologi Penelitian Kesehatan. Jakarta: Rhineka Cipta.

Nurhida dkk. (2016). Hubungan Pengetahuan Dengan Perilaku Vulva Hygiene Pada Saat Menstruasi Remaja Putri. Jurnal Ilmu Keperawatan. 4(1): 50 - 57.

Rohmani dkk. (2013). Karakteristik Demam Berdarah Dengue pada Anak di Rumah Sakit Roemani Semarang. Jurnal Kedokteran Muhammadiyah 1(2) : 93 98.

Satyawan dan Pasek. (2013). Hubungan Persepsi Dan Tingkat Pengetahuan Penderita TB Dengan Kepatuhan Pengobatan Di Kecamatan Buleleng. Jurnal Pendidikan Indonesia. 2(1): 145 152.

Sigarlaki, H. J. O. (2007). Karakteristik, Pengetahuan, Dan Sikap Ibu Terhadap Penyakit Demam Berdarah Dengue. Berita Kedokteran Masyarakat. 23(3): $148-153$.

Wahyuni, dkk. (2005). Peran Faktor Lingkungan dan Perilaku Terhadap Penularan Demam Berdarah Dengue di Kota Mataram. Jurnal Kesehatan Lingkungan. 2 (2): $1-10$. 